\title{
U17 CEV Avrupa Erkekler Voleybol Şampiyonası İçin Konya'ya Gelen Takım Kafilelerinin Kültürel Mirasa Temasının Değerlendirilmesi*
}

\author{
Assessment of Teams' Visit to Culltural Heritage in 2017 Cev U17 Men Volleyball \\ European Championship in Konya
}

\author{
ORİJINAL ARAŞTIRMA/ \\ ORIGINAL RESEARCH \\ Hicran HALAÇ${ }^{\mathbf{} \dagger}$, \\ Fikret BADEMCi'²,
}

\author{
${ }^{1}$ Eskişehir Teknik Üniversitesi, \\ Eskişehir \\ https://orcid.org/0000-0001-8046-9914 \\ ${ }^{2}$ Frrat Üniversitesi, Elazı $\breve{g}$ \\ https://orcid.org/0000-0003-4860-9416
}

$\ddot{\mathbf{O z}}$

Spor tanımlamalarında genel itibariyle yarışma, rekabet, mücadele ön plana çıksa da temelde bakıldığında spor eğlence, dostluk, macera vb. aktiviteleri de içinde barındıran kültürel bir etkinliktir. Bireyler sporla birlikte sosyalleșir, kültürlerini öğrenir ve onlarla bütünleşir. Organizasyon yapılan kentlerde farklı kültürlerle iletişime geçerek onlar hakkında bilgi edinme şansı elde eder. Çalışmanın amacı; 17 yaş altı kategorisinde ilk Avrupa Şampiyonası olma özelliği taşıyan U17 CEV Avrupa Erkekler Voleybol Şampiyonası için Konya'ya gelen sporcu kafilelerinin Konya'daki kültürel mirasa ne kadar temas ettiklerini araştırmak, sporcuların gittikleri kentlerin kültürel mirasına temasını artırmak adına öneriler sunmaktır. Bu bağlamda şampiyonaya katılan ülke takımlarının sporcularına anket uygulanmıștır. Calıșmada önce kuramsal alt yapı oluşturulmuştur. Ardından 2017 yılında düzenlenen U17 CEV Avrupa Erkekler Voleybol Şampiyonası için Konya'ya gelen takım kafilelerinin kültürel mirasa temasları değerlendirilerek temasın artırılabilmesi için öneriler sunulmuştur. Yapılan çalıșmada sporcuların yaşadıkları şehirlerdeki kültürel miraslara temas ettikleri görülürken spor organizasyonlarının yapıldı ̆̆ı şehirlerde sporcuların kültürel miraslara temaslarının az olduğu görülmüştür. Şampiyonaya katılan sporcuların çoğunluğunun spor organizasyonlarına ev sahipliği yapan şehrin kültürünü tanımayı istediği ancak şampiyona esnasındaki boş zamanlarında tarihi mekânların gezilmesini istemediği görülmektedir. Sporcuların görüşleri doğrultusunda spor organizasyonlarında ev sahibi kentin kültürel miraslarının tanıtımı ile ilgili alternatif metodların üretilmesi gerekliliği öne çıkmaktadır.

Anahtar Kelimeler: Kültürel miras, Spor turizmi, Uluslararası spor organizasyonları, U17 CEV Avrupa Erkekler Voleybol Şampiyonas1, Konya.

\begin{abstract}
In the sport definition, competition and struggle come to the fore but basically, sport is an cultural activity that also includes entertainment, friendship, adventure and so on. Individuals socialize with sports, learn their culture and integrate with them. They gain the chance to obtain information about them cultures through communicating with different cultures. The aim of the study; to research of teams' visit to cultural heritage in the U17 CEV European Men's Volleyball Championship in Konya, which is the first European Championship in the under-17 age category and to offer suggestions to increase the contact of the athletes to the cultural heritage of the cities. In this context, a survey was conducted on the athletes of the country teams participating in the championship. Firstly, theoretical background was provided and the information in the related literature was included. Then, it will evaluate the contacts of the teams coming to Konya for the U17 CEV European Men's Volleyball Championship, which was held in 2017, to the cultural heritage and suggestions was presented to increase contact. In the study, it is seen that while athletes have contacted the cultural heritage in the cities where they live, it is seen that the athletes have little contact with cultural heritage in the cities where sports organizations are made. it is seen that while most of the athletes participating in the Championship want to recognize the culture of the city, which hosts sports organizations, does not want to visit historical places during their free time during the championship. In line with the views of athletes, alternative methods for the promotion of cultural heritage of the host city in sport organizations should be produced. Keywords: Cultural heritage, Sport tourism, International sport organizations, U17 CEV European Men's Volleyball Championship, Konya.
\end{abstract}

\footnotetext{
* Bu çalışma 21-24 Mart 2019 tarihleri arasında Manisa'da düzenlenen II. Dünya Spor Bilimleri Araştırmaları Kongresi’nde sözel bildiri olarak sunulmuştur.

† Sorumlu yazar: Hicran Halaç, hhhalac@eskisehir.edu.tr
} 


\section{GİRIŞ}

Kültür kavramı birçok kişi ve kurum tarafından farklı şekillerde tanımlanmıştır. Farklı tanımları ortak bir paydada buluşturan UNESCO 1982 yılında yayımladığı Dünya Kültür Politikaları Konferansı Sonuç Bildirgesi’nde kültürü, “bir toplumu ya da toplumsal bir grubu tanımlayan belirgin maddi, manevi, zihinsel ve duygusal özelliklerin bileşiminden oluşan bir bütün ve sadece bilim ve edebiyatı değil, aynı zamanda yaşam biçimlerini, insanın temel haklarını, değer yargılarını, geleneklerini ve inançlarını da kapsayan bir olgu”(UNESCO, 1982) olarak tanımlamaktadır. Kültür olgusunun içerisinde yer alan öğeler nesilden nesile aktarılarak miras niteliği kazanmıştır (Gündüz, 2016).

Kültürel miras geniş kapsamı dolayısıyla somut ve somut olmayan kültürel miras olarak iki başlık altında incelenmektedir (Can, 2009). Yapılar, anıtlar, sitler, tablolar vb. dokunulabilir nitelikteki öğeler somut kültürel miras olarak tanımlanmaktadır. Gelenek, görenek, dans, yemek, şarkı vb. öğeler ise UNESCO’nun “toplulukların, grupların ve kimi durumlarda bireylerin, kültürel miraslarının bir parçası olarak tanımladıkları uygulamalar, temsiller, anlatımlar, bilgiler, beceriler ve bunlara ilişkin araçlar, gereçler ve kültürel mekânlar"(UNESCO, 2003) olarak tanımladığı somut olmayan kültürel miras kavramı içinde yer almaktadır. Somut ve somut olmayan kültürel miras tanım olarak farklılaşsa da birbirleriyle dinamik bir ilişki içindedirler. "Ne maddi kültürü, etrafinda oluşan ritüellerden, pratiklerden, anlatma biçimlerinden, ne de somut olmayan kültürel mirası maddi bağlamından soyutlayarak tam olarak kavramak mümkündür” (Basat, 2013).

Bireyleri fiziksel, ruhsal ve sosyal açılardan geliştiren spor, çağdaş toplumların oluşmasında ve gelişmesinde etkili olan, toplumları tanıtan sosyo-kültürel bir olgudur. Sporun sosyal yapısı onu kültürün bir parçası haline getirmektedir. "Spor, ekonomik, sosyal ve kültürel kalkınmanın temel unsuru olan insanın beden ve ruh sağlı̆̆ını geliştirmek, kişiliğin oluşumunu, karakter özelliklerinin gelişimini sağlamak, bilgi, beceri ve yetenek kazandırarak çevreye uyumu kolaylaştırmak, kişiler, toplumlar ve uluslararası dayanışma, kaynaşma ve barışı sağlamak, kişinin mücadele gücünü arttırmak yanında belli kurallara göre rekabet ölçüleri içerisinde mücadele etme, heyecan duyma, yarışma ve yarışmada üstün gelme amacıyla yapılan faaliyetlerdir"(Yetim, 2000). Bireylerin sosyal çevrelere katılması yönüyle spor, bireyin sosyalleşmesi üzerinde etkili bir hal almakta ve bireylerin toplumsal kültürlerini öğrenmelerini, 
Halaç, H., ve Bademci, F. (2019). U17 CEV Avrupa erkekler voleybol şampiyonası için Konya'ya gelen takım kafilelerinin kültürel mirasa temasının değerlendirilmesi. CBÜ Beden Eğitimi ve Spor Bilimleri Dergisi, 14(2), 234248.

kültürle bütünleşmelerini ve toplumsal düzene uyum sağlamalarına yardımcı olmaktadır (Yıldız, 2015). Sporun sosyal bir uğraş olması kültür ile sporun birbirinin ayrıştırılamaz parçaları haline gelmesini sağlamaktadır. Özellikle büyük spor organizasyonlarında spor aktivitelerine katılmak ya da takip etmek amacıyla yapılan kentsel bazda hareketlerin oluşturduğu spor turizmi sayesinde kültürlerin kaynaşması ve yayılması da sağlanmaktadır. Büyük spor organizasyonlarının yanında kültür kaynaşmasının sağlanabilmesi için düzenlenen küçük sosyal aktiviteler de sporun bileşenleridir. Ancak günümüzde spor, rekabet duygusunun ötesine geçememektedir (Özer, 2011). Spor organizasyonuna katılan bireylerle organizasyona ev sahipliği yapılan kentler ve kentlerin kültürleri arasında etkileşim sağlanamamaktadır (Halaç ve Bademci, 2019). Oysaki sporun temel amaçlarından bir tanesi toplumlarının kültürel değerlerinin tanıtımıdır. Spor organizasyonların kapsamında yapılan turizm hareketleri kişilere gidilen yörenin tarihi, sosyal yaşantısı, kültürel mirasları gibi birçok alanda bilgi sağlayabilmektedir.

Spor aktivitelerine katılan bireylerin yanı sıra organizasyonları izlemek ve takip etmek amacıyla organizasyonun düzenlendiği kente giden bireylerin oluşturdukları spor turizmi ülkeye yaptığı döviz girdileriyle turizm endüstrisinin önemli alt bileşenlerinden biri haline gelmiştir. Çalışmanın amacı U17 CEV Avrupa Erkekler Voleybol Şampiyonası için Konya'ya gelen takım kafilelerinin tarihi mekânlara olan ilgisini, katıldıkları turnuvalardaki şehirlerde ve Konya'da tarihi mekânlara ne kadar temas ettiklerini ve ne kadar temas etmek istediklerini incelemek ve sporcuların kültürel miraslara daha fazla temas edebilmeleri için öneriler sunmaktır. Bu amaç doğrultusunda literatür araştırması yapılmış olup turnuvaya katılan voleybolculara ve antrenörlere nicel veri toplama yöntemlerinden anket uygulanmıştır. Ankette açık uçlu ve çoktan seçmeli sorulara yer verilmiştir.

\section{YÖNTEM}

Çalışmada U17 CEV Avrupa Erkekler Voleybol Şampiyonası için Konya'ya gelen takım kafilelerine Halaç, Bademci ve Çeliksoy tarafından 2017 yılında yayımlanan "TBF Uluslararası U16 Yıldız Erkekler Turnuvası İçin Konya'ya Gelen Takım Kafilelerinin, Kültürel Mirasa Temasının Değerlendirilmesi” adlı çalışmada uygulanan anketin geliştirilmesiyle oluşturulan bir anket uygulanmıştır. Şampiyonada yaş ve cinsiyet sınırlaması olmasından dolayı ankette yaş ve cinsiyet belirlenmesine yönelik sorulara yer verilmemiştir. Anket, bir tanesi sporcunun hangi 
Halaç, H., ve Bademci, F. (2019). U17 CEV Avrupa erkekler voleybol şampiyonası için Konya'ya gelen takım kafilelerinin kültürel mirasa temasının değerlendirilmesi. CBÜ Beden Eğitimi ve Spor Bilimleri Dergisi, 14(2), 234248.

ülkeden katıldığının belirlenmesine yönelik olmak üzere toplam 19 sorudan oluşmaktadır. Anket, açık uçlu, sıralı seçenekli kapalı uçlu ve sırasız seçenekli kapalı uçlu soru tiplerinden oluşmaktadır. Ankette sporcuların kültürel miraslara olan ilgililerinin, yaşadıkları kentteki kültürel miras bilgilerinin ve Konya'da bulundukları süre zarfinda kültürel mirasa ne kadar temas ettiklerinin ölçülebileceği sorular yer almaktadır. Ankette yer alan sorulara verilen yanıtların frekans değerleri IBM SPSS Statistics 20 programına aktarılarak analiz edilmiştir.

\section{BULGULAR}

Avrupa Voleybol Konfederasyonu'nun erkekler ilk kez 2017 yılında düzenlediği CEV U17 Erkekler Avrupa Voleybol Şampiyonası'nın final etabı 3-11 Temmuz 2017 tarihleri arasında son yıllarda birçok uluslararası spor organizasyonuna ev sahipliği yapan Konya'da gerçekleştirildi. Müsabakalar Konya Büyükşehir Spor ve Kongre Merkezi'nde bulunan 500 ve 10.000 kişilik 2 salonda oynandı. Organizasyonun final etabına CEV Bölgesel Birlik Şampiyonası 1. etap eleme turnuvası birincileri; Yunanistan, Rusya, Çekya, Finlandiya, İtalya ve U17 Erkekler Avrupa Şampiyonası 2. etap eleme grup birincileri; Bulgaristan, Sırbistan, Belçika, Hollanda, Beyaz Rusya, U17 Erkekler Avrupa Şampiyonası 2. Etap Eleme grupları en iyi ikincisi İspanya ve ev sahibi Türkiye katıldı. 1 Ocak 2001 tarihi sonrasında doğan sporcuların katıldığı organizasyonun final etabı statü gereği 2 grup şeklinde oynandı. Gruplarda ilk 4 sırayı alan İtalya, Belçika, Türkiye ve Bulgaristan şampiyonluk için mücadele etti. İlk kez düzenlenen CEV U17 Erkekler Avrupa Voleybol Şampiyonası'nın şampiyonu Belçika'yı 3-2 yenen İtalya oldu.

Tablo 1. Turnuva Kafilesinde Bulunan ve Ankete Katılan Sporcu Sayılarının Ülkelere Göre Dağılımı

\begin{tabular}{lrr}
\hline Takım & Frekans & Katılımcı Sayısı \\
\hline Bulgaristan & 12 & 7 \\
Belçika & 12 & 0 \\
İtalya & 12 & 6 \\
Türkiye & 14 & 7 \\
Hollanda & 12 & 7 \\
Yunanistan & 12 & 3 \\
Beyaz Rusya & 12 & 0 \\
Rusya & 12 & 3 \\
Çekya & 12 & 4 \\
İspanya & 12 & 3 \\
Sirbistan & 12 & 4 \\
Finlandiya & 12 & 3 \\
Toplam & $\mathbf{1 4 6}$ & $\mathbf{4 7}$ \\
\hline Katılım Yüzdesi & & $\mathbf{3 2 , 1 9}$ \\
\hline
\end{tabular}


Halaç, H., ve Bademci, F. (2019). U17 CEV Avrupa erkekler voleybol şampiyonası için Konya'ya gelen takım kafilelerinin kültürel mirasa temasının değerlendirilmesi. CBÜ Beden Eğitimi ve Spor Bilimleri Dergisi, 14(2), 234248.

Turnuvaya katılan takım kafilelerinin kültürel mirasa olan ilgilerinin ve Konya'daki kültürel miraslara temaslarının araştırılması amacıyla sporculara anket uygulanmıştır. Turnuvaya katılan 12 ülke milli takımındaki 146 voleybolcunun 47'si ankete katılmıştır (Tablo 1).

Tablo 1'e bakıldığında Belçika ile Beyaz Rusya milli takımlarının sporcularından anketlere katılımının olmadığı görülmektedir. Diğer yandan Bulgaristan, Hollanda, İtalya ve Türkiye milli takım sporcularının ankete ilgi göstererek yoğun bir katılım sağladığı görülmektedir.

Tablo 2. "Yaşadığınız şehirde bulunan tarihi mekânları gezdiniz mi?" sorusuna verilen yanıtların dağılımı

\begin{tabular}{lrr}
\hline Takım & Evet (\%) & Hayır (\%) \\
\hline Türkiye & 71,4 & 14,3 \\
İtalya & 100 & 0 \\
Bulgaristan & 85,7 & 14,3 \\
Hollanda & 85,7 & 14,3 \\
Rusya & 100 & 0 \\
Sirbistan & 50 & 25 \\
Yunanistan & 100 & 0 \\
İspanya & 100 & 0 \\
Cekya & 100 & 0 \\
Finlandiya & 0 & 100 \\
\hline Toplam & $\mathbf{8 0 , 9}$ & $\mathbf{1 4 , 9}$ \\
\hline
\end{tabular}

Ankette yer alan "Yaşadı̆̆ınız şehirde bulunan tarihi mekânları gezdiniz mi? ” sorusuna 47 kişilik örneklemin 45’i $(\% 95,8)$ cevap verirken sporcuların tarihi mekânlara ilgili oldukları göze çarpmaktadır. Katılımcıların \%80,9’u yaşadığı şehirde bulunan tarihi mekânları gezdiğini ifade ederken \%14,9'u ise gezmediğini belirtmiştir. Finlandiya, Çekya, İspanya, Yunanistan, Rusya ve İtalya takımlarından katılımcıların tamamı soruya 'Evet' cevabını verirken Hollanda ve Bulgaristan takımlarından olan katılımcıların \%85,7'si, Türkiye takımından olan katılımcıların \%71,4'ü, Sırbistan takımından olan katılımcıların \%50’si 'Evet' cevabını vermiştir. İtalya, Rusya, Yunanistan, İspanya ve Çekya milli takımı oyuncularından ankete katılanların tamamı yaşadıkları kentlerde bulunan tarihi mekânları gezdiklerini belirtirken Finlandiya milli takımı oyuncularından ankete katılanların ise tam aksine tarihi mekânlara ilgilerinin olmadığı görülmektedir (Tablo 2). 
Halaç, H., ve Bademci, F. (2019). U17 CEV Avrupa erkekler voleybol şampiyonası için Konya'ya gelen takım kafilelerinin kültürel mirasa temasının değerlendirilmesi. CBÜ Beden Eğitimi ve Spor Bilimleri Dergisi, 14(2), 234248.

Tablo 3. "Turnuvalar dışında gittiğiniz şehirlerde tarihi mekânları ziyaret eder misiniz?" sorusuna verilen yanıtların dağılımı

\begin{tabular}{|c|c|c|c|c|c|}
\hline Takım & $\begin{array}{r}\text { Evet } \\
\%\end{array}$ & $\begin{array}{r}\text { Çoğunlukla } \\
\%\end{array}$ & $\begin{array}{r}\text { Kimi Zaman } \\
\%\end{array}$ & Nadiren \% & $\begin{array}{r}\text { Hayır } \\
\%\end{array}$ \\
\hline Türkiye & 28,6 & 0 & 28,6 & 28,6 & 14,3 \\
\hline İtalya & 16,7 & 33,3 & 0 & 16,7 & 16,7 \\
\hline Bulgaristan & 28,6 & 14,3 & 0 & 57,1 & 0 \\
\hline Hollanda & 42,9 & 14,3 & 28,6 & 14,3 & 0 \\
\hline Rusya & 0 & 33,3 & 0 & 66,7 & 0 \\
\hline Surbistan & 25 & 25 & 25 & 0 & 0 \\
\hline Yunanistan & 0 & 33,3 & 33,3 & 33,3 & 0 \\
\hline İspanya & 0 & 33,3 & 33,3 & 0 & 0 \\
\hline Çekya & 25 & 25 & 0 & 50 & 0 \\
\hline Finlandiya & 0 & 0 & 33,3 & 66,7 & 0 \\
\hline Toplam & 21,3 & 19,1 & 17 & 31,9 & 4,3 \\
\hline
\end{tabular}

Ankette yer alan “Turnuvalar dışında gittiğiniz şehirlerde tarihi mekânları ziyaret eder misiniz?" sorusunu 44 katılımcı yanıtlamıştır. Katılımcıların \%21,3'ü soruya 'Evet' cevabını verirken \%19,1'i 'Çoğunlukla', \%17'si 'Kimi Zaman', \%31,9'u 'Nadiren', \%4,3'ü ise 'Hayır' cevabını vermiştir. Katılımcıların büyük çoğunluğu turnuvalar dışında gittikleri şehirlerde tarihi mekânları nadiren ziyaret etkilerini söylerken az sayıdaki katılımcı ise tarihi mekânları ziyaret etmediklerini ifade etmiştir. Tablo 3'e bakıldığında Hollanda milli takımından olan katılımcıların diğer ülkelere nazaran turnuva dışında gidilen ülkedeki tarihi mekânlara daha fazla temas ettikleri görülürken Finlandiya milli takımından olan katılımcıların ise daha az temas ettiği görülmektedir (Tablo 3).

Tablo 4. "Turnuvalar dışında gittiğiniz şehirlerdeki tarihi mekânlar hakkında önceden bilgi edinir misiniz?" sorusuna verilen yanıtların dağılımı

\begin{tabular}{lrr}
\hline Takım & Evet (\%) & Hayır (\%) \\
\hline Türkiye & 28,6 & 57,1 \\
İtalya & 50 & 50 \\
Bulgaristan & 42,9 & 57,1 \\
Hollanda & 14,3 & 71,4 \\
Rusya & 33,3 & 66,7 \\
Sirbistan & 75 & 25 \\
Yunanistan & 66,7 & 33,3 \\
İspanya & 33,3 & 33,3 \\
Çekya & 50 & 50 \\
Finlandiya & 0 & 100 \\
\hline Toplam & $\mathbf{3 8 , 3}$ & $\mathbf{5 3 , 2}$ \\
\hline
\end{tabular}

Ankette yer alan "Turnuvalar dışında gittiğiniz şehirlerdeki tarihi mekânlar hakkında önceden bilgi edinir misiniz? ” sorusunu 43 katılımcı (\%91,5) yanıtlamıştır. Tablo 4'e bakıldığında katılımcıların \%53,2'sinin turnuva dışında gidilen şehirlerde bulunan tarihi mekânlar hakkında araştırma yapmadığı görülmektedir. Tarihi mekânlar hakkında en fazla araştırmayı Sırbistan milli 
Halaç, H., ve Bademci, F. (2019). U17 CEV Avrupa erkekler voleybol şampiyonası için Konya'ya gelen takım kafilelerinin kültürel mirasa temasının değerlendirilmesi. CBÜ Beden Eğitimi ve Spor Bilimleri Dergisi, 14(2), 234248.

takımı sporcularının yaptığı görülürken en az araştırmayı ise Finlandiya takımı sporcularının yaptığı görülmektedir.

Tablo 5. "Spor organizasyonlarında tarihi mekânları ziyaret etmeye ve yöresel lezzetler tatmaya yer verilmesi gerektiğini düşünüyor musunuz?" sorusuna verilen yanıtların dağılımı

\begin{tabular}{lrrrr}
\hline Takım & $\begin{array}{r}\text { İkisi De } \\
\text { Gerekli (\%) }\end{array}$ & $\begin{array}{r}\text { Yöresel } \\
\text { Lezzetler (\%) }\end{array}$ & $\begin{array}{r}\text { Tarihi } \\
\text { Mekânlar (\%) }\end{array}$ & $\begin{array}{r}\text { Íkisi De } \\
\text { Gerekli Değil (\%) }\end{array}$ \\
\hline Türkiye & 71,4 & 0 & 0 & 28,6 \\
İtalya & 33,3 & 0 & 66,7 & 0 \\
Bulgaristan & 0 & 14,3 & 85,7 & 0 \\
Hollanda & 28,6 & 0 & 14,3 & 57,1 \\
Rusya & 0 & 33,3 & 0 & 66,7 \\
Sirbistan & 50 & 25 & 0 & 0 \\
Yunanistan & 66,7 & 0 & 0 & 33,3 \\
İspanya & 66,7 & 0 & 33,3 & 0 \\
Çekya & 25 & 0 & 0 & 75 \\
Finlandiya & 33,3 & 0 & 0 & 66,7 \\
\hline Toplam & $\mathbf{3 8 , 3}$ & $\mathbf{4 , 3}$ & $\mathbf{2 5 , 5}$ & $\mathbf{2 9 , 8}$ \\
\hline
\end{tabular}

Ankette yer alan "Spor organizasyonlarında tarihi mekânları ziyaret etmeye ve yöresel lezzetler tatmaya yer verilmesi gerektiğini düşünüyor musunuz?” sorusunu 46 sporcu $(\% 97,9)$ cevaplamıştır. Ankete katılan sporcuların büyük çoğunluğunun spor organizasyonlarında kültürel etkinliklere yer verilmesi gerektiği görüşünü savunduğu görülürken \%29,8'lik kısmının ise organizasyonlarda kültürel etkinliklerin gereksiz olduğu görüşüne sahip olduğu görülmektedir. Çekya, Rusya, Finlandiya ve Hollanda milli takımı sporcularının çoğunluğu organizasyonlarda kültürel etkinliklere yer verilmemesi gerektiği görüşünü savunmaktadırlar. Türkiye milli takımı sporcularınınsa büyük kısmı iki etkinliğe de yer verilmesi gerektiğini belirtmişlerdir. Bulgaristan ve İtalya milli takım sporcularının büyük kısmı ise sadece tarihi mekânlara temas edilmesi gerektiğini ifade etmişlerdir (Tablo 5).

Tablo 6. "Sportif müsabakalar ya da turnuvalar için gittiğiniz şehirlerde, tarihi mekânları ziyaret eder misiniz?" sorusuna verilen yanıtların dağılımı

\begin{tabular}{lrrrr}
\hline Takım & Hayır (\%) & Bazen (\%) & Çoğu Zaman (\%) & Her Firsatta (\%) \\
\hline Türkiye & 0 & 0 & 28,6 & 71,4 \\
İtalya & 0 & 16,7 & 33,3 & 50 \\
Bulgaristan & 0 & 14,3 & 71,4 & 14,3 \\
Hollanda & 0 & 28,6 & 57,1 & 14,3 \\
Rusya & 33,3 & 33,3 & 33,3 & 0 \\
Sirbistan & 0 & 0 & 25 & 50 \\
Yunanistan & 33,3 & 33,3 & 33,3 & 0 \\
İspanya & 0 & 0 & 100 & 0 \\
Çekya & 25 & 25 & 0 & 0 \\
Finlandiya & 0 & 66,7 & 33,3 & 0 \\
\hline Toplam & $\mathbf{6 , 4}$ & $\mathbf{1 9 , 1}$ & $\mathbf{4 2 , 6}$ & $\mathbf{2 5 , 6}$ \\
\hline
\end{tabular}


Halaç, H., ve Bademci, F. (2019). U17 CEV Avrupa erkekler voleybol şampiyonası için Konya'ya gelen takım kafilelerinin kültürel mirasa temasının değerlendirilmesi. CBÜ Beden Eğitimi ve Spor Bilimleri Dergisi, 14(2), 234248.

Ankette yer alan "Sportif müsabakalar ya da turnuvalar için gittiğiniz şehirlerde, tarihi mekânlarl ziyaret eder misiniz?" sorusuna 44 sporcu $(\% 93,7)$ cevap vermiştir. Tablo 6'ya bakıldığında milli takım kafilelerinin turnuva için gidilen şehirlerde tarihi mekânları ziyaret etme konusuna özen gösterdikleri görülmektedir. Takımlar arasından Türkiye ve İspanya milli takımlarının diğer takımlara nazaran tarihi mekân gezilerine daha fazla önem verdikleri görülmektedir. Bu takımları İtalya ve Bulgaristan milli takımları takip ederken takımlar arasında tarihi mekân gezilerine en az önem veren ülke olarak Çekya ön plana çıkmaktadır.

Tablo 7. "Sportif müsabakalar için gideceğiniz şehirleri, ne tür özelliklere sahip olduğu yönüyle, gitmeden önce araștırır mısınız?” sorusuna verilen yanıtların dağılımı

\begin{tabular}{lrr}
\hline Takım & Evet (\%) & Hayır (\%) \\
\hline Türkiye & 28,6 & 71,4 \\
İtalya & 83,3 & 16,7 \\
Bulgaristan & 42,9 & 57,1 \\
Hollanda & 28,6 & 71,4 \\
Rusya & 0 & 100 \\
Sirbistan & 50 & 25 \\
Yunanistan & 33,3 & 66,7 \\
İspanya & 66,7 & 33,3 \\
Çekya & 25 & 75 \\
Finlandiya & 0 & 100 \\
\hline Toplam & $\mathbf{3 8 , 3}$ & $\mathbf{5 9 , 6}$ \\
\hline
\end{tabular}

Ankette yer alan "Sportif müsabakalar için gideceğiniz şehirleri, ne tür özelliklere sahip olduğu yönüyle, gitmeden önce araştırır mısınız?” sorusuna 43 sporcu $(\% 97,9)$ yanıt vermiştir. Tablo 7'ye bakıldığında sporcuların büyük kısmının, turnuvalara gitmeden önce organizasyona ev sahipliği yapacak şehir hakkında araştırma yapmadıkları görülmektedir. Bununla birlikte İtalya ve İspanya milli takım oyuncularının gidecekleri şehir hakkında araştırma yapma yüzdelerinin diğer takımlara göre yüksek olduğu, Finlandiya ve Rusya milli takımlarından ankete katılan sporcuların hiçbirinin şehir hakkında araştırma yapmadığı görülmektedir.

Tablo 8. "Konya'ya gelmeden önce Konya'yı araştırdınız mı?” sorusuna verilen yanıtların dağılımı

\begin{tabular}{lrr}
\hline Takım & Evet (\%) & Hayır (\%) \\
\hline Türkiye & 28,6 & 71,4 \\
İtalya & 66,7 & 33,3 \\
Bulgaristan & 0 & 85,7 \\
Hollanda & 28,6 & 28,6 \\
Rusya & 33,3 & 66,7 \\
Sirbistan & 75 & 0 \\
Yunanistan & 0 & 100 \\
İspanya & 33,3 & 66,7 \\
Cekya & 25 & 0 \\
Finlandiya & 33,3 & 0 \\
\hline Toplam & $\mathbf{3 1 , 9}$ & $\mathbf{4 6 , 8}$ \\
\hline
\end{tabular}


Halaç, H., ve Bademci, F. (2019). U17 CEV Avrupa erkekler voleybol şampiyonası için Konya'ya gelen takım kafilelerinin kültürel mirasa temasının değerlendirilmesi. CBÜ Beden Eğitimi ve Spor Bilimleri Dergisi, 14(2), 234248.

Ankette yer alan "Konya'ya gelmeden önce Konya'yı araştırdınız mı?” sorusuna 37 sporcu $(\% 78,7)$ cevap vermiştir. Tablo 8'e bakıldığında sporcuların Konya hakkında pek fazla araştırma yapmadığı anlaşılmaktadır. Konya hakkında araştırma yapan sporcu yüzdesinin en fazla olduğu takım \%75 ile Sırbistan iken Bulgaristan ve Yunanistan milli takımlarından soruyu yanıtlayan sporcuların hiçbirinin Konya hakkında araştırma yapmadığı görülmektedir.

Tablo 9. "Konya'da kaldığınız süre boyunca, boş zamanlarınızın tarihi mekânların görülmesi için planlanmasını ister miydiniz?" sorusuna verilen yanıtların dağılımı

\begin{tabular}{lrr}
\hline Takım & Evet (\%) & Hayır (\%) \\
\hline Türkiye & 57,1 & 42,9 \\
İtalya & 66,7 & 16,7 \\
Bulgaristan & 28,6 & 71,4 \\
Hollanda & 14,3 & 85,7 \\
Rusya & 33,3 & 66,7 \\
Sirbistan & 75 & 25 \\
Yunanistan & 33,3 & 66,7 \\
İspanya & 100 & 0 \\
Çekya & 25 & 75 \\
Finlandiya & 33,3 & 6,7 \\
\hline Toplam & $\mathbf{4 4 , 7}$ & $\mathbf{5 1 , 1}$ \\
\hline
\end{tabular}

Ankette yer alan "Konya'da kaldığınız süre boyunca, boş zamanlarınızın tarihi mekânların görülmesi için planlanmasını ister miydiniz?" sorusuna 47 sporcunun 45'i $(\% 95,8)$ cevap vermiştir. Sporcuların \%51,1'i seçeneklerde yer alan 'Hayır' şıkkını işaretlerken \%44,7'si de 'Evet' şıkıını işaretlemiştir. Tablo 9'a bakıldığında İspanya milli takımından ankete katılan sporcuların tamamı Konya'da bulundukları süre içerisinde boş zamanlarının tarihi mekânların görülmesi için planlanmasını istediklerini belirtmişlerdir. İspanya' y1 \%75 ile Sırbistan ve \%66,7 ile İtalya takip etmiştir. Soruya verilen cevaplar arasında 'Hayır' seçeneğinin en yoğun olarak tercih edildiği takım ise Hollanda milli takımı olmuştur. Hollanda'yı \%71,4 ile Bulgaristan ve $\% 66,7$ ile Rusya takip etmiştir.

Tablo 10. "Konya'ya gelmeden önce Konya'da nereleri görmek istiyordunuz?" sorusuna verilen yanıtlar

\begin{tabular}{lrrrrrrr}
\hline Takım & $\begin{array}{l}\text { Mevlana Müz. } \\
(\%)\end{array}$ & Sille (\%) & Avm (\%) & $\begin{array}{r}\text { Sema T. } \\
(\%)\end{array}$ & $\begin{array}{r}\text { Alaaddin T. } \\
(\%)\end{array}$ & $\begin{array}{r}\text { Aya Elena K. } \\
(\%)\end{array}$ & Hiçbiri (\%) \\
\hline Türkiye & 85,7 & 28,6 & 57,1 & 0 & 0 & 0 & 0 \\
İtalya & 100 & 16,7 & 16,7 & 16,7 & 33,3 & 16,7 & 0 \\
Bulgaristan & 0 & 28,6 & 28,6 & 0 & 57,1 & 28,6 & 28,6 \\
Hollanda & 0 & 14,3 & 0 & 0 & 0 & 14,3 & 85,7 \\
Rusya & 100 & 0 & 0 & 0 & 0 & 0 & 0 \\
Sirbistan & 50 & 0 & 0 & 0 & 50 & 0 & 0 \\
Yunanistan & 0 & 0 & 0 & 0 & 0 & 0 & 66,7 \\
İspanya & 100 & 0 & 0 & 33,3 & 33,3 & 33,3 & 0 \\
Çekya & 25 & 0 & 25 & 25 & 0 & 0 & 75 \\
Finlandiya & 0 & 0 & 0 & 0 & 0 & 0 & 100 \\
\hline Toplam & $\mathbf{4 0 , 4}$ & $\mathbf{1 2 , 8}$ & $\mathbf{1 7}$ & $\mathbf{6 , 4}$ & $\mathbf{1 9 , 1}$ & $\mathbf{1 0 , 6}$ & $\mathbf{3 4}$ \\
\hline
\end{tabular}


Halaç, H., ve Bademci, F. (2019). U17 CEV Avrupa erkekler voleybol şampiyonası için Konya'ya gelen takım kafilelerinin kültürel mirasa temasının değerlendirilmesi. CBÜ Beden Eğitimi ve Spor Bilimleri Dergisi, 14(2), 234248.

Ankette yer alan "Konya'ya gelmeden önce Konya'da nereleri görmek istiyordunuz?” sorusuna katılımcıların tamamı cevap vermiştir. Birden fazla seçeneğin işaretlenebildiği soruda katılımcıların en çok görmek istedikleri yer \%40,4 ile Mevlana müzesi olmuştur. Mevlana müzesini \%19,1 ile Alaaddin Tepesi, \%17 ile AVM, \%12,8 ile Sille, \%10,6 ile Aya Elena Kilisesi ve \%6,4 ile Sema törenleri takip etmiştir. Katılımcıların \%34’ü ise 'hiçbiri' seçeneğini tercih etmiştir (Tablo 10).

Yunanistan ve Finlandiya milli takımlarından ankete katılan sporcuların tamamının hiçbir mekânı görmek istemedikleri dikkat çekmektedir. İtalya, Rusya ve İspanya takımlarının tamamı Mevlana Müzesi'ni görmek isterlerken Hollanda, Bulgaristan ve Finlandiya milli takımlarından ankete katılan sporcuların hiçbirisinin Mevlana Müzesini görmek istemediği görülmektedir. Öte yandan katılımcıların tarihi mekânlara olan ilgisinin AVM'lere olan ilgilerine göre daha fazla olduğu anlaşılmaktadır. AVM'ye en fazla ilgi duyan milli takım ise Türkiye milli takımı olmuştur.

Tablo 8 ile Tablo 10 birlikte değerlendirildiğinde Yunanistan milli takımı sporcularının Konya hakkında bilgisi olmadığı ve hiçbir mekânı görmek istemedikleri görülmektedir. Bulgaristan milli takımı sporcularının ise Konya hakkında bilgisi olmamasına karşın Konya'daki farklı mekânları görmek istedikleri anlaşılmaktadır. Konya hakkında bilgiye sahip olan sporcu sayısının fazla olduğu Sırbistan milli takımında ise sporcuların Mevlana Müzesi ve Alaaddin Tepesi’ni görmek istedikleri görülmektedir.

Tablo 11. "Konya'da bulunduğunuz zaman diliminde, herhangi bir tarihi mekânı ziyaret ettiniz mi?" sorusuna verilen yanıtların dağılımı

\begin{tabular}{lrr}
\hline Takım & Evet (\%) & Hayır (\%) \\
\hline Türkiye & 85,7 & 14,3 \\
İtalya & 83,3 & 16,7 \\
Bulgaristan & 0 & 100 \\
Hollanda & 100 & 0 \\
Rusya & 100 & 0 \\
Surbistan & 100 & 0 \\
Yunanistan & 0 & 100 \\
İspanya & 0 & 100 \\
Çekya & 0 & 100 \\
Finlandiya & 0 & 100 \\
\hline Toplam & $\mathbf{5 3 , 2}$ & $\mathbf{4 6 , 8}$ \\
\hline
\end{tabular}

Ankette yer alan 'Konya'da bulunduğunuz zaman diliminde, herhangi bir tarihi mekânı ziyaret ettiniz mi?" sorusuna katılımc1ların tamamı cevap verirken katılımc1ların \%53,2'sinin tarihi mekânları ziyaret ettiği \%46.8'inin ise ziyaret etmediği görülmektedir. Hollanda, Rusya ve Sırbistan milli takımlarından ankete katılan sporcuların tamamının tarihi mekânları ziyaret ettiği 
Halaç, H., ve Bademci, F. (2019). U17 CEV Avrupa erkekler voleybol şampiyonası için Konya'ya gelen takım kafilelerinin kültürel mirasa temasının değerlendirilmesi. CBÜ Beden Eğitimi ve Spor Bilimleri Dergisi, 14(2), 234248.

görülürken Türkiye milli takımından ankete katılan sporcuların \%85,7'sinin, İtalya milli takımından ankete katılan sporcuların \%83,3'ünün tarihi mekânları ziyaret ettiği görülmektedir. Yunanistan, İspanya, Çekya ve Finlandiya milli takımlarından ankete katılan sporcuların ise hiçbirinin tarihi mekânlara temas etmediği görülmektedir (Tablo 11).

Tablo 12. "Ziyaret ettiğiniz tarihi mekân1/mekânları lütfen belirtiniz." cümlesine verilen yanıtların dağılımı

\begin{tabular}{lrrrrr}
\hline Takım & $\begin{array}{r}\text { Mevlana } \\
\text { Müzesi (\%) }\end{array}$ & Sille (\%) & $\begin{array}{r}\text { Alaaddin } \\
\text { Tepesi (\%) }\end{array}$ & $\begin{array}{r}\text { Aya Eleni } \\
\text { kilisesi (\%) }\end{array}$ & Hiçbiri (\%) \\
\hline Türkiye & 100 & 0 & 0 & 0 & 0 \\
İtalya & 66,7 & 0 & 0 & 0 & 33,3 \\
Hollanda & 0 & 28,6 & 0 & 0 & 71,4 \\
Rusya & 100 & 0 & 0 & 0 & 0 \\
Surbistan & 25 & 0 & 0 & 0 & 75 \\
\hline Toplam & $\mathbf{5 8 , 3}$ & $\mathbf{5 , 7}$ & $\mathbf{0}$ & $\mathbf{0}$ & $\mathbf{3 6}$ \\
\hline
\end{tabular}

Tarihi mekânları ziyaret eden sporcuların en çok gittikleri mekân Mevlana Müzesi olurken Türkiye ve Rusya milli takımlarından ankete katılan sporcuların tamamının Mevlana Müzesi’ni ziyaret ettikleri görülmektedir. Mevlana Müzesi'ni Sille takip ederken Alaaddin Tepesi ve Aya Elena Kilisesine hiç gidilmediği görülmüştür (Tablo 12).

Katılımcılar, Mevlana Müzesi ve Sille’yi tercih etmelerinde, antrenörler tarafindan bu mekânların tercih edilmesinin, mekânın geçmişinin çok eskilere dayanmasının, rehberlerinin tavsiyesinin ve takımın ortak tercihi olmasının etkili olduğunu belirtmişlerdir.

Tablo 13. "Konya'da bulunduğunuz zaman diliminde, Sema Töreni izlediniz mi?" sorusuna verilen yanıtların dağılımı

\begin{tabular}{lrr}
\hline Takım & Evet (\%) & Hayır (\%) \\
\hline Türkiye & 28,6 & 71,4 \\
İtalya & 16,7 & 83,3 \\
Bulgaristan & 14,3 & 85,7 \\
Hollanda & 14,3 & 85,7 \\
Rusya & 0 & 100 \\
Sirbistan & 0 & 100 \\
Yunanistan & 0 & 100 \\
İspanya & 0 & 100 \\
Çekya & 0 & 50 \\
Finlandiya & 0 & 100 \\
\hline Toplam & $\mathbf{1 0 , 6}$ & $\mathbf{8 5 , 1}$ \\
\hline
\end{tabular}

Ankette yer alan "Konya'da bulunduğunuz zaman diliminde, Sema Töreni izlediniz mi?”, sorusuna 47 katılımcının 45'i $(\% 95,7)$ cevap vermiştir. Konya'da bulunulan süre içerisinde sporcuların \%10,6'sının sema törenini izlediği görülürken \%85,1'inin sema töreni izlemediği görülmektedir (Tablo 13). UNESCO Dünya Somut Olmayan Kültür Miras Temsili Listesinde yer 
Halaç, H., ve Bademci, F. (2019). U17 CEV Avrupa erkekler voleybol şampiyonası için Konya'ya gelen takım kafilelerinin kültürel mirasa temasının değerlendirilmesi. CBÜ Beden Eğitimi ve Spor Bilimleri Dergisi, 14(2), 234248.

alan sema töreninin Konya'da haftada 2 gün yapılmasına karşın sporcuların büyük çoğunluğunun bu kültürel mirası izlemediği görülmektedir.

Tablo 14. "Gezdiğiniz tarihi mekânları beğendiniz mi?” sorusuna verilen yanıtların dağılımı

\begin{tabular}{lrr}
\hline Takım & Evet (\%) & Hayır (\%) \\
\hline Türkiye & 51,7 & 28,6 \\
İtalya & 50 & 50 \\
Hollanda & 85,7 & 0 \\
Rusya & 0 & 100 \\
Sirbistan & 100 & 0 \\
\hline Toplam & $\mathbf{5 7 , 5}$ & $\mathbf{3 5 , 7}$ \\
\hline
\end{tabular}

Ankette yer alan "Gezdiğiniz tarihi mekânlarl beğendiniz mi?" sorusuna soruyu cevaplayan sporcuların \%57,5'i 'Evet' yanıtını verirken \%35,7'si ise 'Hayır' yanıtını vermiştir (Tablo 14). "Beğenme ve beğenmeme sebepleriniz nelerdir?” sorusuna ise sadece beğenen sporcular cevap vermiştir. Sporcuların mekânları beğenme kriterleri arasında, mekânların eski ve tarihi oluşları, bireylerin dini yapılara olan ilgileri, bireylerin tarihi mekânlara olan ilgileri, kendi ülkeleri ile karşılaştırarak farklı olduğu kanaatine varmaları ve Türk kültürlerini sevmeleri bulunmaktadır.

Ankette yer alan, "Gözlemlediğiniz kadarıyla Konya'yı nasıl tanımlayabilirsiniz?” sorusuna katılımcılar, "akşamları çok güzel, arkadaş canlısı, büyük bir şehir, dini bir şehir, parkları ve yollarda ağaçları olan yeşil bir şehir, büyük salonları olan bir şehir, ilginç bir şehir, zengin bir şehir, düz, sade ve rahat bir şehir, güzel şehir, insanlarının kültürlerine ve dinine bağlı olduğu bir şehir, kötü şoförlerle dolu olan bir şehir, mükemmel bir şehir” cevaplarını vermişlerdir.

Tablo 15. "Konya'yı tekrar ziyaret etmek ister misiniz?" sorusuna verilen yanıtların dağılımı

\begin{tabular}{lrrrrr}
\hline Takım & Kesinlikle Evet (\%) & Evet (\%) & Belki (\%) & Hayır (\%) & Kesinlikle Hayır (\%) \\
\hline Türkiye & 0 & 0 & 71,4 & 28,6 & 0 \\
İtalya & 0 & 0 & 16,7 & 50 & 33,3 \\
Bulgaristan & 28,6 & 28,6 & 14,3 & 28,6 & 0 \\
Hollanda & 14,3 & 42,9 & 14,3 & 0 & 28,6 \\
Rusya & 0 & 66,7 & 33,3 & 0 & 0 \\
Sirbistan & 50 & 0 & 25 & 0 & 25 \\
Yunanistan & 0 & 33,3 & 33,3 & 33,3 & 0 \\
İspanya & 0 & 0 & 0 & 100 & 0 \\
Çekya & 25 & 0 & 25 & 0 & 25 \\
Finlandiya & 33,3 & 66,7 & 0 & 0 & 0 \\
\hline Toplam & $\mathbf{1 7}$ & $\mathbf{2 1 , 3}$ & $\mathbf{2 5 , 5}$ & $\mathbf{2 3 , 4}$ & $\mathbf{1 2 , 8}$ \\
\hline
\end{tabular}

Ankette yer alan “Konya'yı tekrar ziyaret etmek ister misiniz?” sorusuna katılımcıların tamamı cevap vermiştir. Katılımcıların en çok yoğunlaştığı seçenek \%25,5 ile 'Belki' olurken 
Halaç, H., ve Bademci, F. (2019). U17 CEV Avrupa erkekler voleybol şampiyonası için Konya'ya gelen takım kafilelerinin kültürel mirasa temasının değerlendirilmesi. CBÜ Beden Eğitimi ve Spor Bilimleri Dergisi, 14(2), 234248.

'Belki' seçeneğini \%23,4 ile 'Hayır', \%21,3 ile 'Evet', \%17 ile 'Kesinlikle Evet' ve \%12,8 ile 'Kesinlikle Hayır' seçenekleri takip etmiştir (Tablo 15).

Tablo 16. "Yakın çevrenizdekilere Konya'yı ziyaret etmelerini önerir misiniz?” sorusuna verilen yanıtların dağılımı

\begin{tabular}{lrr}
\hline Takım & Evet (\%) & Hayır (\%) \\
\hline Türkiye & 85,7 & 14,3 \\
İtalya & 66,7 & 33,3 \\
Bulgaristan & 57,1 & 28,6 \\
Hollanda & 71,4 & 28,6 \\
Rusya & 66,7 & 33,3 \\
Sirbistan & 75 & 25 \\
Yunanistan & 66,7 & 33,3 \\
İspanya & 0 & 100 \\
Çekya & 75 & 25 \\
Finlandiya & 100 & 0 \\
\hline Toplam & $\mathbf{6 8 , 1}$ & $\mathbf{2 5 , 5}$ \\
\hline
\end{tabular}

Ankette yer alan "Yakın çevrenizdekilere Konya'yı ziyaret etmelerini önerir misiniz?" sorusuna katılımcıların 44’ü $(\% 93,6)$ cevap vermiştir. Katılımcıların \%68,1'i yakın çevresine Konya'yı ziyaret etmelerini önereceğini ifade ederken $\% 25,5$ 'i ise önermeyeceğini belirtmiştir. Soruda yer alan 'Evet' seçeneğinin en fazla tercih edildiği milli takım \%100 ile Finlandiya olurken Finlandiya’yı \%85,7 ile Türkiye, \%75 ile Sırbistan, \%71,4 ile Hollanda takip etmiştir. İspanya milli takımından soruyu cevaplayan sporcuların tamamı ise Konya'yı önermeyeceklerini ifade etmişlerdir (Tablo 16).

\section{TARTIŞMA ve SONUÇ}

CEV U17 Erkekler Avrupa Voleybol Şampiyonası'nda yapılan anketler sonucunda ankete katılan sporcuların büyük kısmının şampiyona için gittikleri şehirler hakkında önceden bilgi edinmedikleri tespit edilmiştir. Ankette, sporcuların yaşadıkları şehirlerde bulunan tarihi mekânları ziyaret ettikleri belirlenirken turnuva haricinde gittikleri kentlerdeki tarihi mekânları ziyaret etme oranlarının daha düşük olduğu belirlenmiştir. Bununla birlikte sporcuların, turnuva için gittikleri şehirlerdeki tarihi mekânları gezdikleri görülmüş ancak Konya'daki turnuvada bu oranın daha düşük olduğu tespit edilmiştir. Sporcuların büyük bir kısmı turnuva için gidilen şehirlerde kültürel değerlerin tanıtımını isterken, turnuva esnasındaki boş zamanların tarihi mekânların görülmesi için planlanmasını istememektedirler. $\mathrm{Bu}$ nedenle turnuva için gidilen şehirlerde kültürel miras tanıtımı sporcuların fazla enerji harcamayacakları etkinliklerle 
Halaç, H., ve Bademci, F. (2019). U17 CEV Avrupa erkekler voleybol şampiyonası için Konya'ya gelen takım kafilelerinin kültürel mirasa temasının değerlendirilmesi. CBÜ Beden Eğitimi ve Spor Bilimleri Dergisi, 14(2), 234248.

yapılmalıdır. Kültürel miras tanıtımı yapılırken sporcuların, turnuva esnasında zorunlu olarak kullanacakları mekânların dışındaki mekânlarda etkinlikler organize edilmemesi faydalı olacaktır.

CEV U17 Erkekler Avrupa Voleybol Şampiyonası'na katılan takım kafilelerinin ev sahibi kenti tanımaları için düzenleme kurulu tarafından bir organizasyon yapılmamıştır. Buna karşın bazı takım kafilelerinin ev sahibi kentte bulunan tarihi mekânları kendi ilgi ve istekleri sonucunda gezdikleri tespit edilmiştir. Uluslararası organizasyonlarda gerek yerel yönetimler gerekse federasyonlar ya da organizasyonla ilgili kurumlar tarafından etkinliklerin düzenlenmesi sporcuların kentlerin kültürel miraslarını tanıması adına yararlı olacaktır.

Şampiyona'da Konya'nın tanıtımı, turnuvanın final gününde salona kurulan stantlarda dağıtılan broşürlerle yapılmıştır. Organizasyonun yapıldığı Konya Büyükşehir Belediyesi Spor ve Kongre merkezine $3 \mathrm{~km}$ uzaklıkta bulunan Mevlana Kültür Merkezi'nde her cumartesi Sema töreni yapılmasına rağmen turnuvaya katılan sporcuların çok az bir kısmı Konya' da sema gösterisi izlemiştir. Kentlerin kültürel miraslarının tanıtıldığı etkinliklerin spor organizasyonunun bir parçası haline getirilmesi organizasyonlarda kültürel miras tanıtımının eksik kalmaması konusunda faydalı olacaktır.

Temel itibariyle sosyo-kültürel bir etkinlik olan spor, günümüzde rekabetin gölgesinde kalmaktadır. Gerek sporculara gerek antrenörlere gerekse şampiyonanın düzenlenmesinde görev alan kişilere sporun sosyo-kültürel bir etkinlik olduğu hatırlatılmalı, şampiyona esnasında bu tür aktivitelere yer verilmelidir. $\mathrm{Bu}$ aktiviteler spor organizasyonlarının birer parçası haline getirilmelidir. Kültürel miras tanıtımıyla ilgili düzenlenecek olan etkinlikler bir yandan kentin tanıtımını sağlarken bir yandan kültürlerarası iletişımi artıracak bir yandan da sporcuların entelektüel kimliğine katkı sağlayacak onların kültürel anlamda gelişmesinde önemli rol oynayacaktır. 
Halaç, H., ve Bademci, F. (2019). U17 CEV Avrupa erkekler voleybol şampiyonası için Konya’ya gelen takım kafilelerinin kültürel mirasa temasının değerlendirilmesi. CBÜ Beden Eğitimi ve Spor Bilimleri Dergisi, 14(2), 234248.

\section{KAYNAKLAR}

Basat, E. (2013). Somut ve somut olmayan kültürel mirası birlikte koruyabilmek. Milli Folklor, 25(100), 61-71.

Can, M. (2009). Kültürel miras ve müzecilik. Çalışma raporu. Kültür ve Turizm Bakanlığı.

Gündüz, Y. (2016). Kültürel miras açısından inanç turizmi: Türkiye örneği. Yüksek lisans tezi. İstanbul Üniversitesi, İstanbul.

Halaç, H. Bademci, F. \& Çeliksoy, M. (2017). TBF uluslararası U16 yıldız erkekler turnuvası için Konya'ya gelen takım kafilelerinin, kültürel mirasa temasının değerlendirilmesi. The Journal of Academic Social Science Studies, 60, $267-279$.

Halaç, H. \& Bademci, F. (2019). Sporcuların kültürel mirasa temasının artırılması. II. Dünya Spor Bilimleri Araştırmaları Kongresi Tam Metin Kitabı içerisinde (ss. 378-382). Manisa Celal Bayar Üniversitesi.

Özer, U., \& Çolakoğlu, T. (2017). Çağdaş spor bilincinin oluşmasında spor yöneticilerinin görüşleri. Ulusal Spor Bilimleri Dergisi, $1(2), 1-11$.

UNESCO. (1982). Dünya Kültür Politikaları Konferansı Sonuç Bildirgesi.

UNESCO. (2003). Somut Olmayan Kültürel Mirasın Korunması Sözleşmesi.

Yetim, A. (2000). Sporun sosyal görünümü. Gazi Beden Eğitimi ve Spor Bilimleri Dergisi, 5(1), 63-72.

Yıldız, Y. (2015). Spor yapan ve spor yapmayan üniversite öğrencilerinin sosyalleşme ve mutluluk düzeylerinin İncelenmesi. Yüksek lisans tezi. Muğla Sitkı Koçman Üniversitesi, Muğla. 